\title{
Light Microscopic Evaluation of Acute and Chronic Hypophyseal Endocrinopathy in a Kaolin-Induced Hydrocephalus Model
}

\author{
Raziye Handan NURHAT ${ }^{1}$, Hakan SABUNCUOGLU², Burak KAZANCI ${ }^{2}$, Ferda TOPAL CELIKKAN ${ }^{3}$, \\ Bizden SABUNCUOGLU ${ }^{3}$
}

\author{
${ }^{1}$ Kirklareli Luleburgaz State Hospital, Department of Neurosurgery, Kirklareli, Turkey \\ ${ }^{2}$ Ufuk University School of Medicine, Department of Neurosurgery, Ankara, Turkey \\ ${ }^{3}$ Ankara University School of Medicine, Department of Histology and Embriology, Ankara, Turkey
}

This study has been presented at the $32^{\text {nd }}$ Turkish Neurosurgical Society Scientific Congress between 20 and 24 April 2018 at Antalya, Turkey.

Corresponding author: Raziye Handan NURHAT rhnurhat@hotmail.com

\section{ABSTRACT}

AIM: To demonstrate progression of acute and chronic endocrinopathies in a kaolin-induced hydrocephalus model using light microscopy.

MATERIAL and METHODS: Adult male Sprague-Dawley rats $(n=48)$ were divided into six groups. Hydrocephalus was induced by intracisternal injection of kaolin solution in the acute and chronic kaolin groups, whereas an identical volume of sterile saline was injected into the sham groups.

RESULTS: Somatotropic cell concentrations were lower in the kaolin groups compared with their controls, but there was no difference in somatotropic cell concentration between the acute and chronic kaolin groups. Corticotropic cell concentrations were higher in the acute kaolin and sham groups compared with acute controls. Thyrotropic cell numbers were higher in the acute sham and kaolin groups compared with their controls, and although thyrotropic cell concentations were higher in the acute kaolin group than the acute sham group. No differences were observed between the acute and chronic controls and sham and kaolin groups regarding mammotropicand gonadototropic cell concentations.

CONCLUSION: Somatotropic cells are most affected by hydrocephalus that causes pituitary dysfunction, and this effect was more prominent under acute and chronic phases.

KEYWORDS: Hydrocephalus, Endocrinopathy, Kaolin, Pituitary dysfunction, Rat

\section{INTRODUCTION}

$\mathrm{H}$ ydrocephalus is more than just a single pathological picture or well-defined disease process. Classical hydrocephalus is the name given to a group of clinical manifestations characterized by increased ventricular enlargement and increased intracranial pressure (ICP) that result in cerebrospinal fluid (CSF) release and impaired imbalance between CSF construction and absorption (3). Congenital hydrocephalus is observed in 3-4 cases in 1000 live births (2). CSF is secreted by the plexus choroideus within the subarachnoid space and serves as a protective cushion against mechanical trauma. Additionally, CSF functions to provide nutrients to the central nervous system, remove metabolites, and deliver hormones secreted from the
Raziye Handan NURHAT (1) : 0000-0001-6803-5128 Hakan SABUNCUOGLU (D): 0000-0001-7286-9942

Burak KAZANCI (1) : 0000-0001-5673-4845
Ferda TOPAL CELIKKAN (1) : 0000-0002-8254-0558

Bizden SABUNCUOGLU (1) : 0000-0002-0152-9761 
hypothalamus to the pituitary (6). Daily CSF production in adults is estimated to be $450-500 \mathrm{~mL}$ (13).

CSF production and absorption are dynamically balanced under normal physiological conditions, and changes in these are regulated by intrinsic compensatory mechanisms. Thus, inhibition of these mechanisms leads to pathological accumulation of CSF.

Hydrocephalus is commonly classified as obstructive (noncommunicating) or non obstructive (communicating), and the relationship referred herein is that between the subarachnoid space and ventricular system (11).

Nonobstructive hydrocephalus occurs during insufficient CSF absorption, e.g., during intraventricular or subarachnoid hemorrhage when CSF absorption from the arachnoid villi is insufficient or made permanently or temporarily impossible by erythrocyte plugs. Further, infections such as meningitis lead to toxin release or scar tissue formation and disrupt arachnoid villi functions. Non obstructive hydrocephalus also occurs due to over production of CSF, and this rare condition is often associated with plexus choroideus papilloma or carcinoma (11).

On the other hand, obstructive hydrocephalus occurs when CSF cannot reach the subarachnoid space from the ventricular system occlusion of the CSF circulatory pathways. This blockage may occur due to congenital malformations of the nervous system, infections or tumors, or any event that affects these pathways (11).

Hydrocephalus can be observed accompanying various endocrine problems, including amenorrhea, precocious puberty, growth retardation, adrenal steroid release at various levels, hypopituitarism, diabetes mellitus, and diabetes insipidus, and primarily occurs due to dysfunction of the hypothalamic and/or pituitary anterior segment. In addition to these problems, hydrocephalus may lead to neuromuscular disorders and learning problems. The most widely accepted mechanism for hydrocephalus-induced endocrine disorders is increased ICP and consequent compression of the hypothalamus and hypophysis due to stretching of the adjacently placed third ventricle (1).

In this study, acute and chronic endocrinopathy processes in the hydrocephalus model formed with kaolin in rats was evaluated using light microscopy.

\section{MATERIALS and METHODS}

\section{Rats and Animal Care}

We used 48 adult (8-week-old) male Sprague-Dawley rats in our study performed at the Kobay Laboratory (Ankara, Turkey), according to ethical principles of animal experimentation; the study was approved by the Ethics Committee. The rats were maintained in a controlled environment with respect to temperature $\left(20^{\circ} \mathrm{C}-25^{\circ} \mathrm{C}\right)$ and photo period (12-hours lightdark cycle; lights switched on at 06:00). Food and water were available ad libitum.
The rats were divided into six groups comprising eight rats each. Group 1 was the acute control group; group 2 was the chronic control group; and group 3 was the acute sham group wherein rats received a sham injection of saline into the cisterna magna and were maintained up to 4 weeks after the injection for development of acute hydrocephalus, if any; group 4 was the chronic sham group that also received a sham injection of saline into the cisterna magna, but rats were maintained till 8 weeks after the injection for development of chronic hydrocephalus, if any; group 5 was the acute kaolin group (experimental group) that received kaolin injection into the cisterna magna, and rats were kept alive for 4 weeks after injection for development of acute hydrocephalus; and group 6 was the chronic kaolin group (experimental group) wherein rats received a kaolin injection and were kept alive for 8 weeks for development of chronic hydrocephalus. Two rats from each group died at different timepoints during the study due to multiple factors (iatrogenic complications, neurological deterioration, decreased scavenging activity, and developing acute hydrocephalus).

\section{Kaolin-Induced Hydrocephalus}

The rats were anesthetized with intraperitoneally injected ketamine $(80 \mathrm{mg} / \mathrm{kg})$, were placed in the supine position, and were fixed from 4 extremities and jaws in the surgical application platform. A 2-cm midline vertical incision was made over the back of the neck from the top of the occiput to $\mathrm{C} 1$, the muscular layers were divided, and the dural membrane overlying the cisterna magna was exposed. In the rats belonging to groups 3 and $4,0.1 \mathrm{~mL}$ saline suspension was injected into the cerebellomedullary cistern after removing an equal volume of cerebrospinal fluid to avoid reflux and/or an abrupt increase in ICP. The injection was slowly administered using an insulin needle. In the rats belonging to groups 5 and $6,0.1 \mathrm{ml}$ kaolin suspension $(250 \mathrm{mg} / \mathrm{mL})$ was injected into the cerebellomedullary cistern after removing an equivalent aliquot of cerebrospinal fluid. In all rats, the muscle layers and skin were sutured, and they were allowed to recover. Notably, more than $80 \%$ of the rats survived after the injection procedure. After recovery from anesthesia, the rats were kept at room temperature, provided with standard chow and water ad libitum, and examined daily for clinical signs of illness.

\section{Animal Sacrifice}

The rats in the acute control, sham, and kaolin (experimental) groups were sacrificed at $4^{\text {th }}$ week, whereas those in the chronic control, sham, and kaolin (experimental) groups were sacrificed at $8^{\text {th }}$ week following the injection. All rats were anesthetized with high-dose ketamine $(200 \mathrm{mg} / \mathrm{kg}$ ) and perfused with neutral buffered $20 \%$ formalin solution by puncturing the left cardiac ventricle. Next, the rats were decapitated, and their brains and pituitary glands were removed and fixed by immersion in $10 \%$ formalin solution for 7 days (Figure 1A-D).

\section{Measurement of Ventricular Distention}

All fixed brains were dissected to facilitate examination of the coronal sections of the cerebrum at the level of the optic chiasm. As an index of ventriculomegaly, the ventricular 

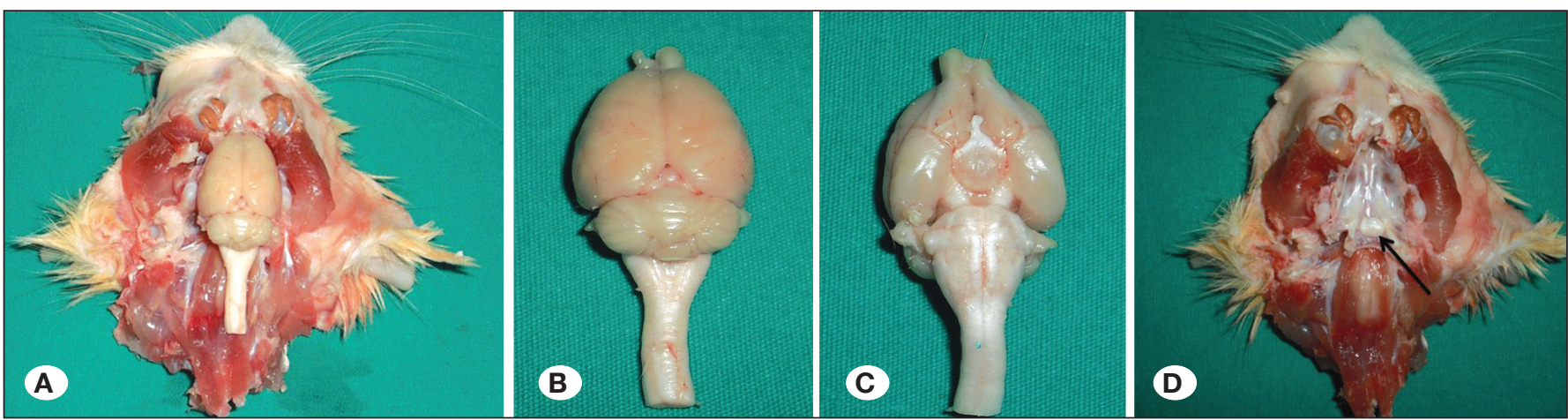

Figure 1: A) Cerebrum, cerebellum, and upper spinal cord of a decapitated rat. B) Excised cerebrum, cerebellum, and upper spinal cord (top view). C) Excised cerebrum, cerebellum, and spinal cord (bottom view). D) Pituitary gland after excising cerebrum, cerebellum, and spinal cord from a decapitated rat (black arrow).

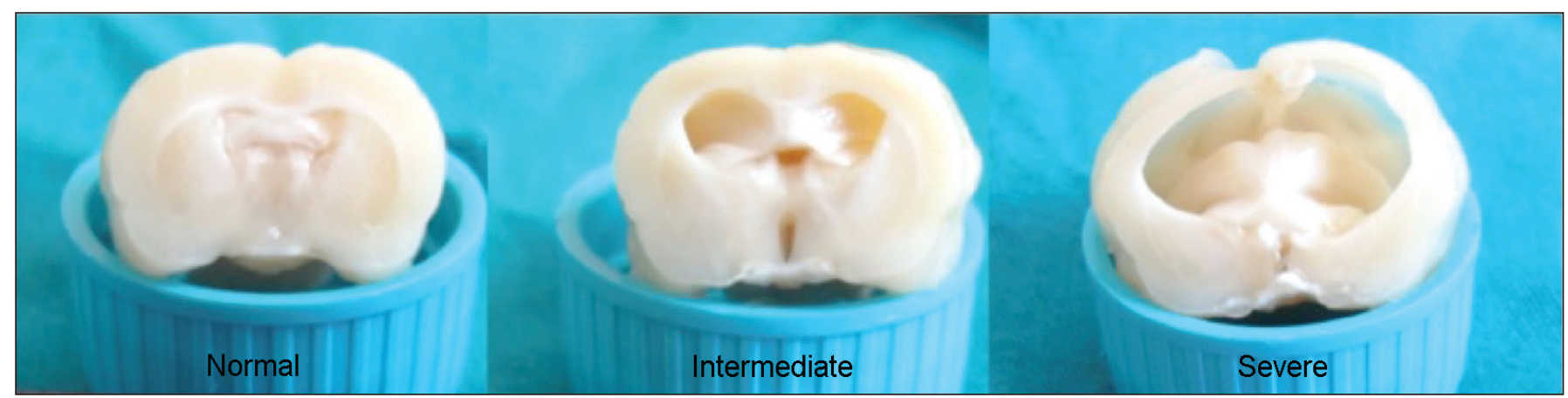

Figure 2: Examples of normal-intermediate and severe hydrocephalus in coronal sections at the chiasma opticum level in the rats.

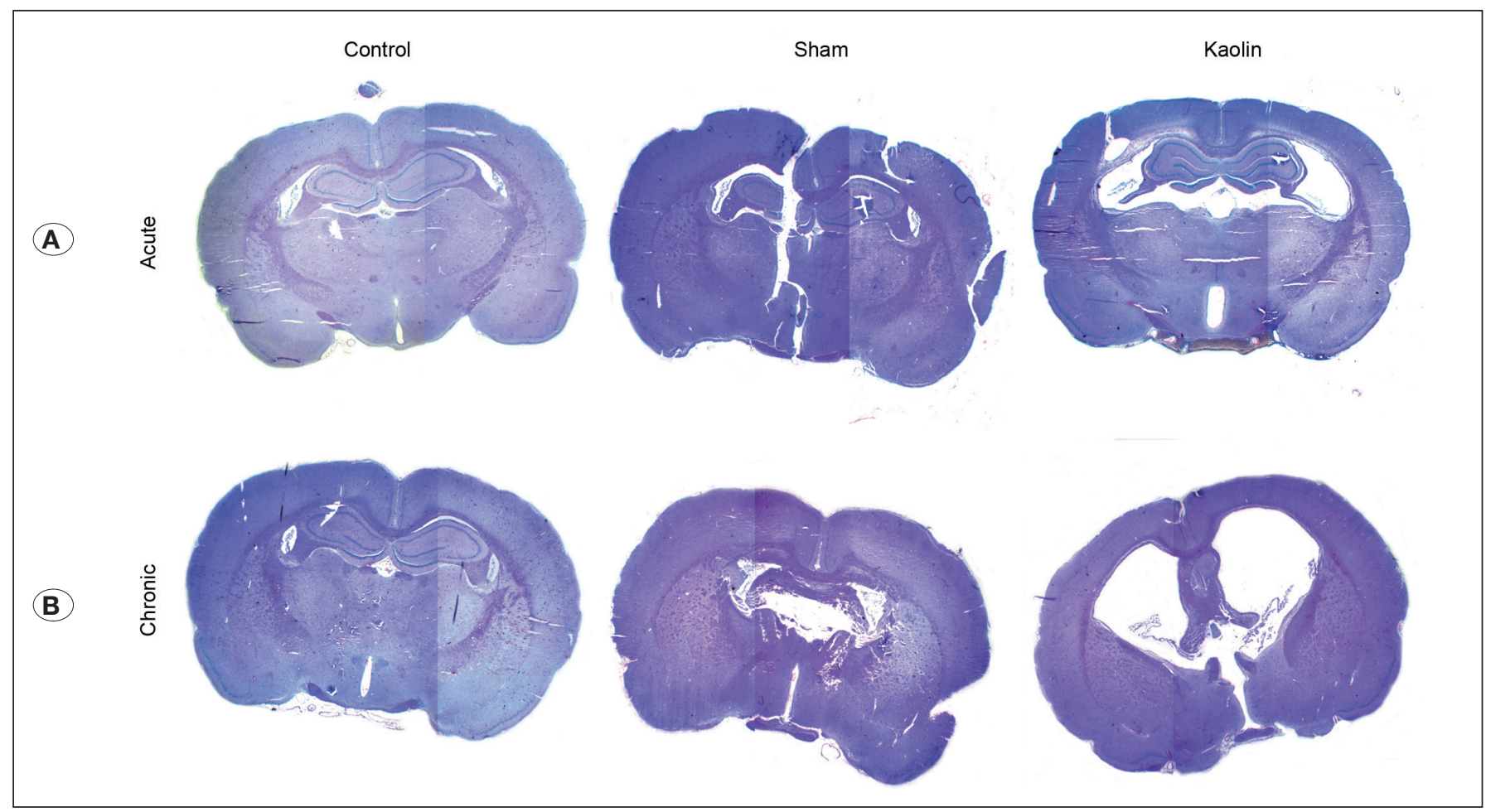

Figure 3: A) Examples of coronal sections from the acute group used in the measurement of hydrocephalus. B) Examples of chronic group coronal sections used in the measurement of hydrocephalus. 
area was quantitated by morphometric analysis using the Magnification 1.6.1 morphometric analysis program (Macbook Pro $2.26 \mathrm{GHz}$ Intel Core 2 Duo, 8 GB $1333 \mathrm{MHz}$ DDR3, Mac OS X 10.9.2) (Figure 2; 3A,B).

\section{Conventional Staining}

Light microscopic examination was performed by the Department of the Histology and Embryology of the Ankara University. For histological analysis, pituitary glands were fixed by immersion in buffered formalin for 7 days. All fixed tissues were subjected to routine histology. Briefly, the tissues were washed in water for 15-20 minutes, dehydrated in an ascending alcohol series $(75 \%, 96 \%$, and $100 \%)$, placed in xylol solutions to make them pellucid, infiltrated, and placed in the incubator for 4 hours at $60^{\circ} \mathrm{C}$. Further, the tissues were embedded in paraffin blocks, and $5-\mu \mathrm{m}$ sections were cut on a microtome (Leica RM 2125RT model sliding microtome, Wetzlar, Germany).

For light microscopic examination, sections were stained with Mallory-Azan (MA) stain, Periodic acid Schiff-Orange G-Light Green (PAS-OG-LG), and aldehyde fuchsin-trichrome (AF-TK; Theory and Practical of Histological Sciences, 2002). Further, the specimens were examined under a light microscope (CarlZeiss Axioskop).

With AF-TK dyeing, thyrotropic cells stain green with fast green, gonadotropic cells stain red with aldehyde fuchsintrichrome, and somatotropic cells stain brown-orange with Orange G. In MA dyeing, somatotropic cells stain brownorange with Orange $\mathrm{G}$, mammotropic cells stain red with azocarmine $\mathrm{G}$, and basophilic cells stain blue with aniline blue. In PAS-OG-LG staining, thyrotropic cells stain blue-purple with PAS, corticotropiccells stain green with light green, and somatotropiccells stain brown-orange with Orange G.

\section{Immunohistochemical Analysis}

Immunohistochemical analysis was performed by the Mikropat Pathology Laboratory. Tissue paraffin blocks from all groups were sectioned at 4-5 micron thickness on poly-lysine slides. Tissue slides were deparaffinized and dehydrated with xylol and alcohol, tissue sections were boiled in $10 \%$ citric said buffer (Thermo Scientific lot: AX 201104) in a microwave oven for 5 min at 400 watts, and for 15 min at 800 watts to facilitate antigen exposure, and the sections were washed with distilled water and phosphate-buffered saline (PBS, pH7.4, Medicago, lot: 162305, Sweden). Further, endogenous peroxidase activity was blocked by incubation in 3\% hydrogen peroxide (Merck, Germany), and the slides were washed with PBS. We used anti-ACTH (anti-ACTH Thermo 452R410C, USA) and anti-GH (anti-GH MCB07, USA) as primary antibodies (1-h incubation at room temperature), blocked slides with normal goat serum to suppress nonspecific binding, and incubated them with secondary antibodies. Diaminobenzidine (DAB, GBI Labs, lot:K126729D, USA) was used as the chromogen to develop the staining. The sections were observed under a light microscope (Carl Zeiss Axioskop) followed by covering Entellan.

\section{Statistical Analysis}

Statistical analysis was performed using the SPSS software program for windows (IBM SPSS Statistics 21 pocket program) and with ANOVA. Statistical significance was defined as $p$ $<0.05$, and the power of the test was defined by the GPower 3.1 program as $95 \%$.

\section{- RESULTS}

\section{Light Microscopic Assessments}

Distribution of cell concentration results according to the groups is shown in Table I.

\section{Acute Hydrocephalus Group}

Corticotropic and thyrotropic cell concentrations were higher in the acute kaolin group compared with that in the acute control group, but somatotropic cell concentrations were lower (Figure 4A-C; 5A, B). Proportion of the other cell groups was similar to that observed in the acute control group (Figure $4 \mathrm{~A}-\mathrm{C})$.

Concentrations of the corticotropic and thyrotropic cells were higher in the acute sham group while those of somatotropic cells were lower (Figure 4A-C). Increase in corticotropic and thyrotropic cells in the acute kaolin group was significantly higher than that in the acute sham group (Figure 4A).

\section{Chronic Hydrocephalus Group}

There were no changes in corticotropic cell concentration in the chronic control, chronic sham, and chronic kaolin groups (Figure 5A; 6A); however, somatotropic cell concentrations were lower in the chronic control group compared with those in the chronic control and chronic sham groups. This decrease in the chronic control group was slightly higher than that in the chronic sham group. Regarding thyrotropic cells, there was a mild increase in the chronic control group compared with the chronic sham and chronic kaolin groups (Figure 5B; 6A-C), and the increase in the chronic control groups was slightly higher than that in the chronic sham group (Figure 6A, C). There were no differences among other cell types (Figure 6A-C).

\section{Somatotropic cell group (Figure 7)}

- There was no significant difference between the acute and chronic groups $(p=0.170)$

\section{- Acute period:}

There was significant difference between the sham and control groups $(p<0.001)$.

There was significant difference between the kaolin and control groups $(p<0.001)$.

\section{- Chronic duration:}

There was significant difference between the sham and control groups $(p<0.001)$.

There was significant difference between the kaolin and control groups $(p<0.001)$. 
Table I: Distribution of Pituitary Cell Groups according to the Study Groups/Results of Pituitary Cell Count

\begin{tabular}{|c|c|c|c|}
\hline Groups & Somatotroph & Corticotroph & Thyrotroph \\
\hline \multicolumn{4}{|l|}{ Acute } \\
\hline Control 1 & 173 & 53 & 20 \\
\hline Control 2 & 150 & 43 & 10 \\
\hline Control 3 & 203 & 50 & 20 \\
\hline Control 4 & 168 & 82 & 8 \\
\hline Control 5 & 149 & 48 & 14 \\
\hline Control 6 & 208 & 72 & 17 \\
\hline Sham 1 & 66 & 248 & 5 \\
\hline Sham 2 & 46 & 89 & 12 \\
\hline Sham 3 & 49 & 177 & 16 \\
\hline Sham 4 & 68 & 219 & 18 \\
\hline Sham 5 & 58 & 233 & 22 \\
\hline Sham 6 & 82 & 141 & 14 \\
\hline Kaolin 1 & 80 & 123 & 21 \\
\hline Kaolin 2 & 49 & 168 & 20 \\
\hline Kaolin 3 & 36 & 144 & 17 \\
\hline Kaolin 4 & 46 & 280 & 14 \\
\hline Kaolin 5 & 60 & 284 & 22 \\
\hline Kaolin 6 & 33 & 263 & 10 \\
\hline \multicolumn{4}{|l|}{ Chronic } \\
\hline Control 1 & 158 & 88 & 5 \\
\hline Control 2 & 190 & 60 & 12 \\
\hline Control 3 & 184 & 59 & 19 \\
\hline Control 4 & 233 & 53 & 17 \\
\hline Control 5 & 216 & 60 & 17 \\
\hline Control 6 & 201 & 54 & 22 \\
\hline Sham 1 & 48 & 54 & 10 \\
\hline Sham 2 & 70 & 67 & 10 \\
\hline Sham 3 & 67 & 50 & 18 \\
\hline Sham 4 & 81 & 87 & 16 \\
\hline Sham 5 & 44 & 78 & 19 \\
\hline Sham 6 & 60 & 44 & 15 \\
\hline Kaolin 1 & 59 & 70 & 18 \\
\hline Kaolin 2 & 57 & 74 & 22 \\
\hline Kaolin 3 & 60 & 85 & 15 \\
\hline Kaolin 4 & 49 & 60 & 20 \\
\hline Kaolin 5 & 50 & 52 & 15 \\
\hline Kaolin 6 & 60 & 50 & 16 \\
\hline
\end{tabular}

\section{Corticotropic cell group (Figure 8)}

- There was a significant difference between the acute and chronic groups $(p<0.001)$.

- Acute period:

There was significant difference between the sham and control groups $(\mathrm{p}<0.001)$.

There was significant difference between the kaolin and control groups $(p<0.001)$.

\section{Thyrotropic cell group (Figure 9)}

- There was no significant difference between the acute and chronic groups $(p=0.276)$.

- Acute period:

There was significant difference between the sham and control groups $(\mathrm{p}<0.013)$.

There was significant difference between the kaolin and control groups $(p<0.011)$.

Figure 10 summarize all the results together for each cell group and for both acute and chronic phases.

\section{DISCUSSION}

One of studies has addressed pathophysiological changes during hydrocephalus in the brain and pituitary response, and Del Bigio et al. summarized these changes in their compilations (5). Periventricular axons seem to be the most important target of damage in cases with hydrocephalus brains. Additionally, focal petechial hemorrhage and axonal damage are seen in acute hydrocephalus, especially in the ventricular horns. In severe hydrocephalus, periventricular white matter atrophy, including that in the corpus callosum of human brains, is a definite finding. Further, hydrocephalus is associated with atrophy of the fornix or fimbrial connections between the hippocampus and anterior brain. Very severe hydrocephalus leads to cerebral cortex degeneration. Atrophy of basal ganglia has also been reported in humans and rats with pathological changes in neurons being secondary to axonal damage. Acute changes are rare unless ICP is elevated and hypoxic/ischemic changes occur (4).

In the study by Löppönen and colleagues, children with shunts were compared with healthy children to assess pubertal development and peripheral concentrations of gonadotropin and sex hormones (8). They found that in children with hydrocephalus, early pubertal maturation occurred in girls and accelerated pubertal maturation in boys with an increase in testicular volume. This phenomenon is attributed to increased gonadotropin levels resulting from non-physiological variations in ICP (8).

In another study, Löppönen and colleagues examined the anatomy and function of the pituitary in 54 hydrocephalic children with shunts and adolescents. Anatomic assessment was performed using ptosis magnetic resonance imaging and sella turcica radiography. Functional values assessed included arginine-insulin test, corticotropin-releasing factor, and the 


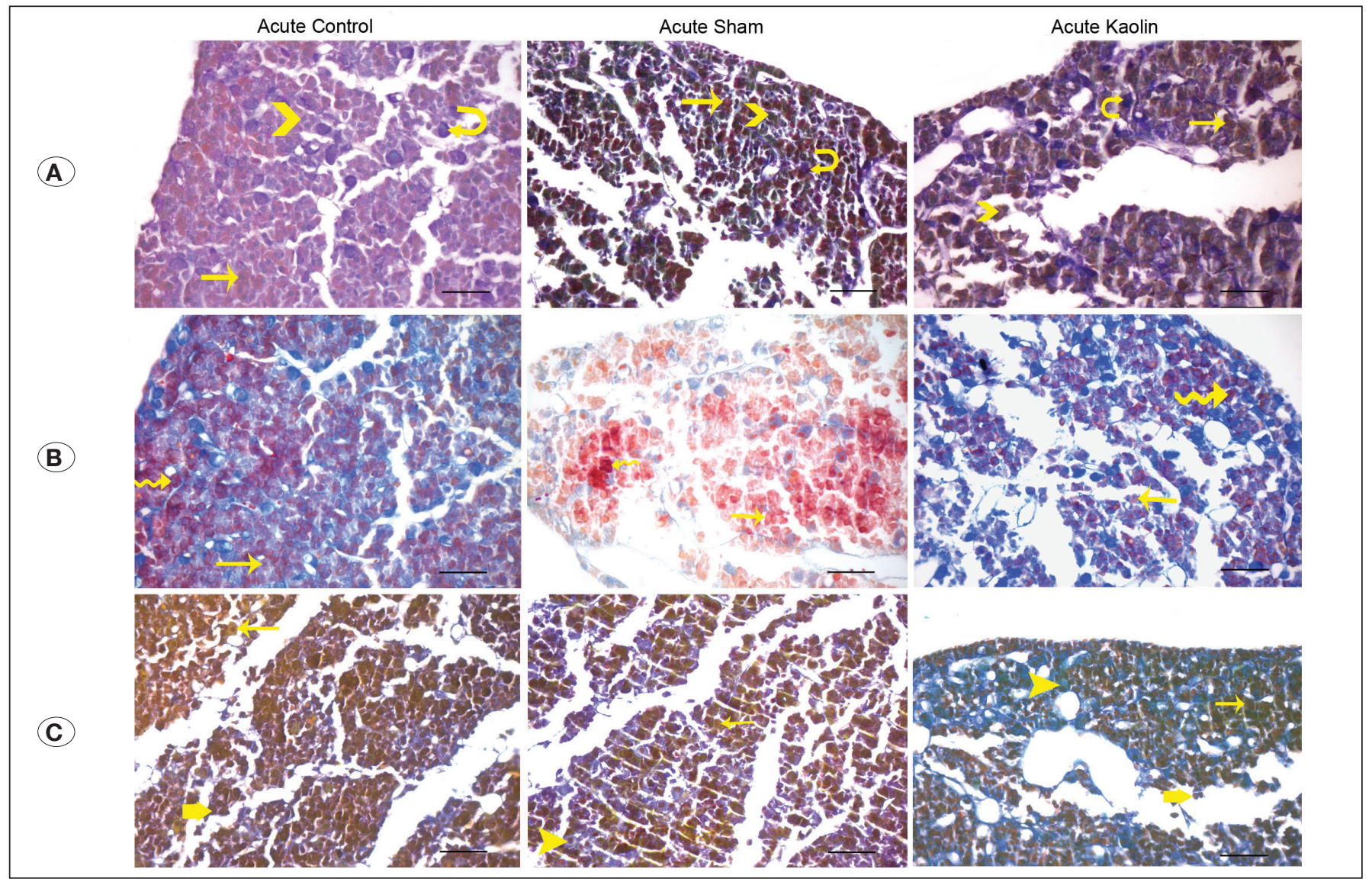

Figure 4: A) Thin arrow,somatotropiccells; oblique arrow, thyrotropiccells; strip, corticotropic cells; Periodic acid Schiff-Orange G-Light Green stain (bar: $50 \mu \mathrm{m}$ ). B) Thin arrow, somatotropiccells; tail arrow, mammotropiccells; Mallory-Azan stain (bar: 50 m). C) Thin arrow, somatotropic cells; arrowhead, thyrotropiccells; thick arrow, gonadotropic cells; aldehyde fuchsin-trichrome stain (bar: $50 \mu \mathrm{m}$ ).

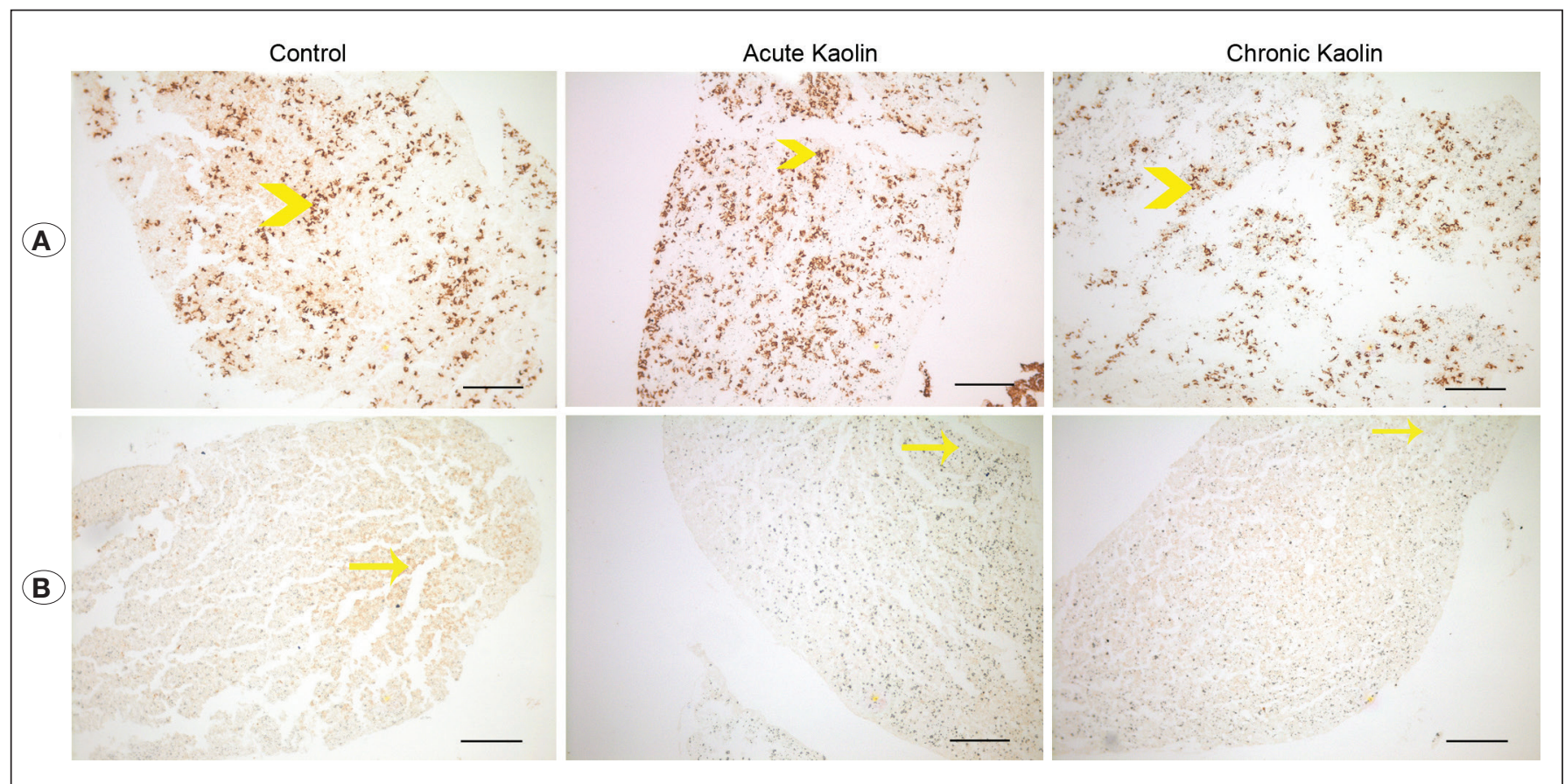

Figure 5: A) Arrowhead, anti-ACTH (bar: $200 \mu \mathrm{m})$. B) Arrowhead, anti-GH (bar: $200 \mu \mathrm{m})$. 


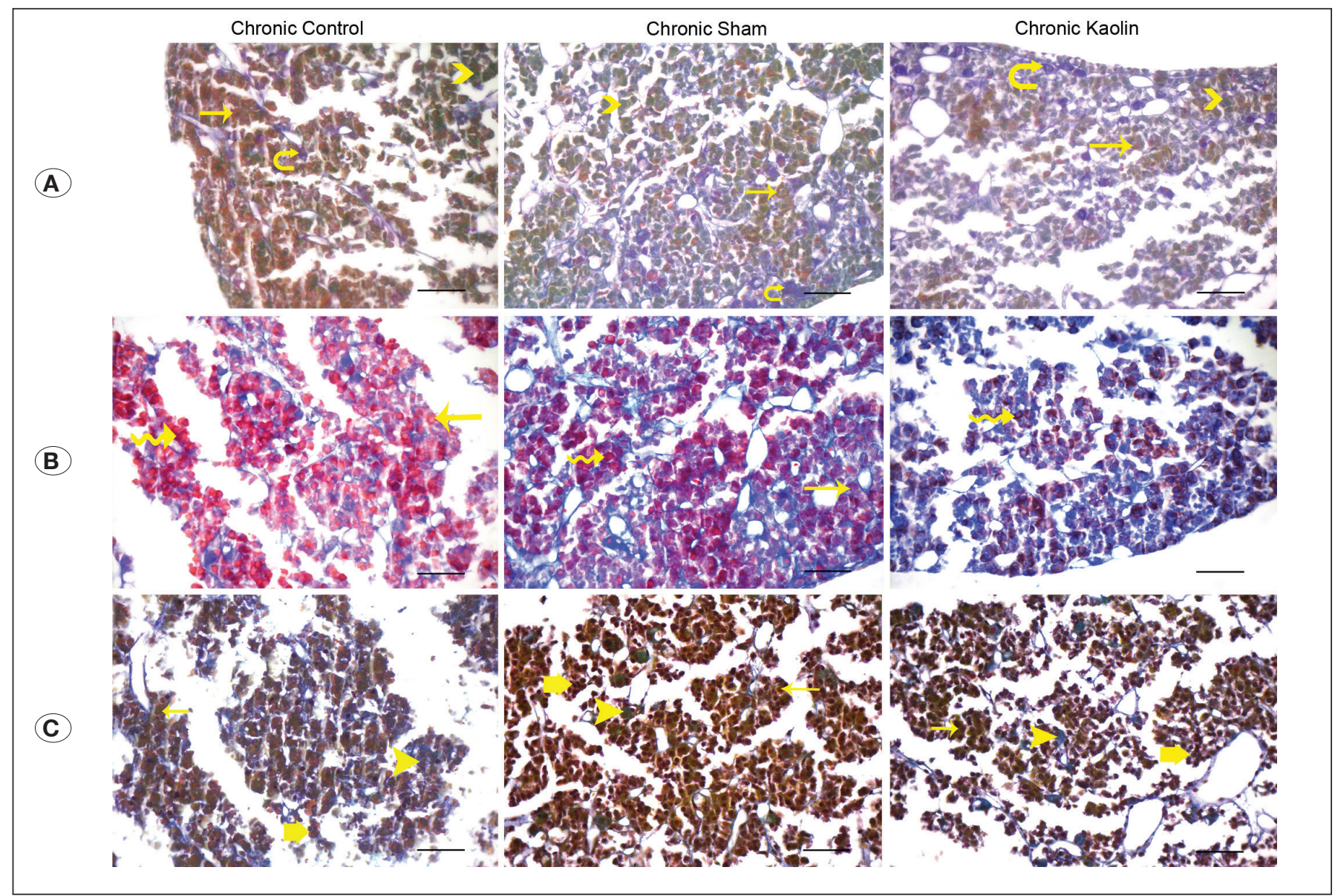

Figure 6: A) Thin arrow, somatotropic cells; oblique arrow; thyrotropiccells; strip, corticotropic cells; Periodic acid Schiff-Orange G-Light Green stain (bar: $50 \mu \mathrm{m})$. B) Thin arrow, somatotrophcells; tail arrow, mammotropic cells; Mallory-Azan stain (bar: 50 mm). C) Thin arrow, somatotropic cells; arrowhead, thyrotropiccells; thick arrow, gonadotropic cells, aldehyde fuchsin-trichrome stain (bar: $50 \mu \mathrm{m})$.

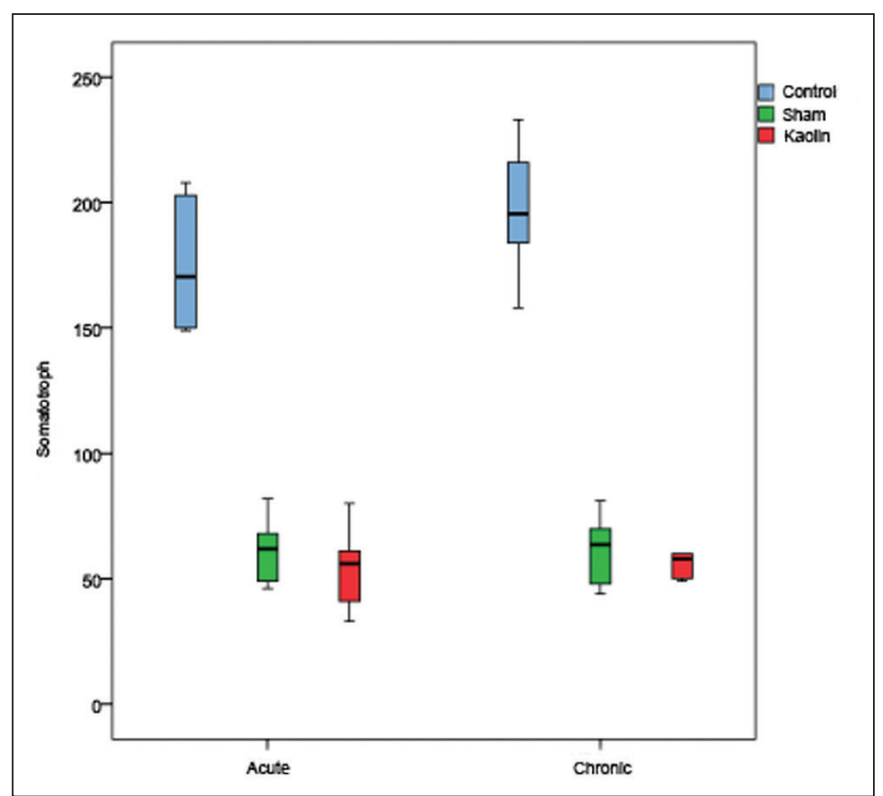

Figure 7: Distribution of somatotropic cell groups in the acute and chronic experimental groups. control group. Patients' baseline GH levels were significantly lower than those of the control group. In 16 patients, the arginine-insulin test elicited a weak $\mathrm{GH}$ response. The pituitary gland height in these patients was significantly lower than that in other patients with normal response to the test. Baseline FSH and LH levels of the patients were also higher than those of the controls, and they correlated to pituitary gland volume. Thus, the mean pituitary gland size was larger in hydrocephalic children with shunts. Further, one-third of these patients had decreased GH release and low pituitary gland elevation; these were considered as reasons for their poor linear growth. Increased pituitary size is associated with increased gonadotropin, possibly resulting in premature puberty in children with shunts (7).

In another study by Löppönen et al, 114 patients with hydrocephalus and shunts were studied. Hydrocephalic children were characterized by slow linear growth at prepubertal stage but with accelerated physical changes during puberty and low final height. In this study, the roles of $\mathrm{GH}$, insulin-like growth factor-1 (IGF-1), and IGF binding protein-3 (IGFBP-3) in determining growth patterns were investigated. Low IGF-1 and IGFBP-3 levels were found in hydrocephalic prepubertal 
children than in the controls. In pubertal children, basal GH levels were found to be 4-times lower. Based on these findings, the authors reported that reduced $\mathrm{GH}$ release contributes to slower linear growth patterns and lower final height (9).

Pituitary functions in patients with normal pressure hydrocephalus (NPH) are not clearly understood. In a study by Moin et al. to determine whether patients with pituitary dysfunction showed improvement after surgery assessed pituitary function in a large series of patients awaiting neurosurgical correction

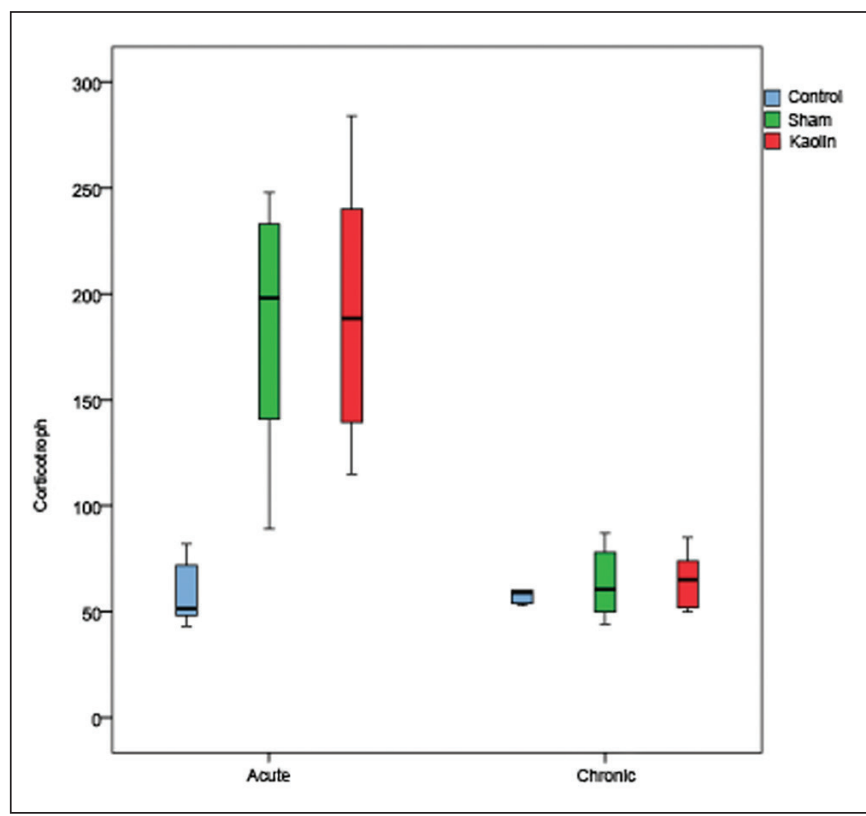

Figure 8: Distribution of corticotropic cells in the acute and chronic experimental groups.

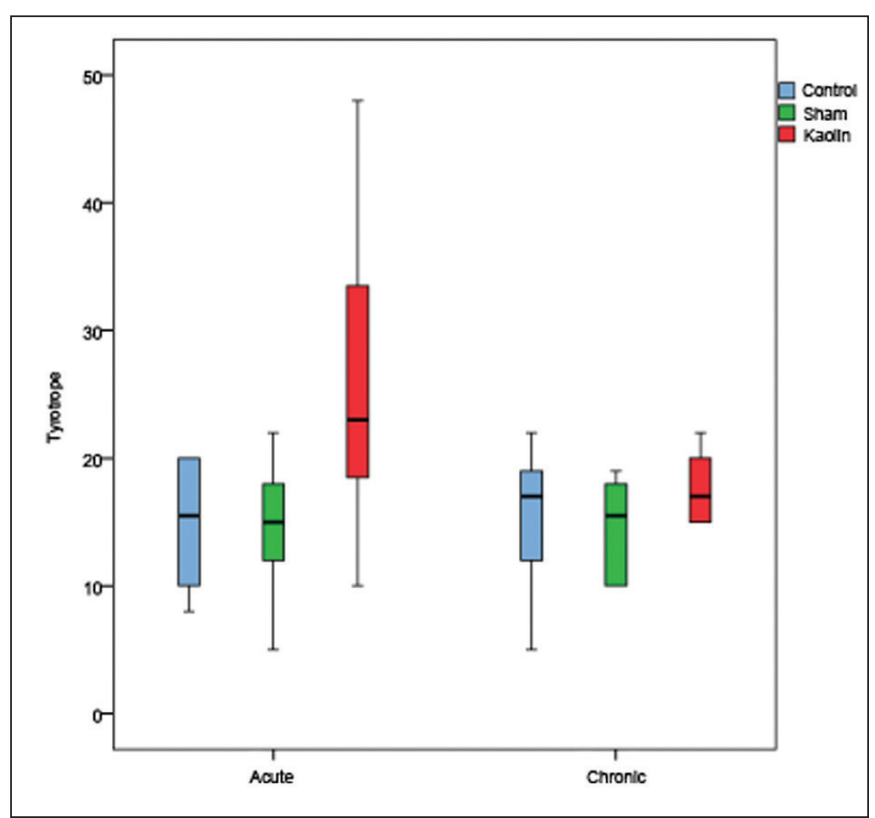

Figure 9: Distribution of thyrotropic cell groups in the acute and chronic experimental groups. for NPH. Between February 2010 and January 2011, patients who underwent surgery were evaluated, and the pituitary endocrine indices, including serum PRL, sTSH, IGF-1, FSH, $\mathrm{LH}$, estradiol, testosterone, cortisol, and ACTH, were evaluated at 1 and 3 months following the surgery. The authors reported that $31 \%$ of these patients had pituitary dysfunction associated with $\mathrm{NPH}$, and the most common type of pituitary dysfunction was hypogonadism. Thus, Moin and colleagues suggest that pituitary imaging should be performed in all patients with $\mathrm{NPH}$. In two patients with hypogonadism, surgical correction of NPH was associated with improvements in testosterone levels. Thus, it is possible that hormone replacement is not needed in all patients with pituitary dysfunction associated with NPH as pituitary deficits in some cases can be surgically corrected (10).

In a study on adult hamsters conducted by Azzi et al., they examined ICP, ventricular dimension, periventricular edema and erythrocyte density, median eminence thickness, and pituitary gland morphology induced by hydrocephalus. Hydrocephalus was created by intracisternal kaolin injection, animals were decapitated, and their pituitary glands were examined. Coronal slices containing paraventricular nucleus, supraoptic nucleus, suprachiasmatic nucleus, subfornical organ, and median eminence were also collected. They reported that pressure induced changes in the endocrine hypothalamus and pituitary gland that led to reduced perfusion, edema, and median eminence (1)

Okada and colleagues reported a case of high somatomedin- $\mathrm{C}$ levels associated with obstructive hydrocephalus. Although somatomedin- $\mathrm{C}$ is known to be the mediator of the human growth hormone, circadian rhythm was absent. However, in the case report, the authors reported an adolescent girl who had high levels of somatomedin-C following shunt blockage and

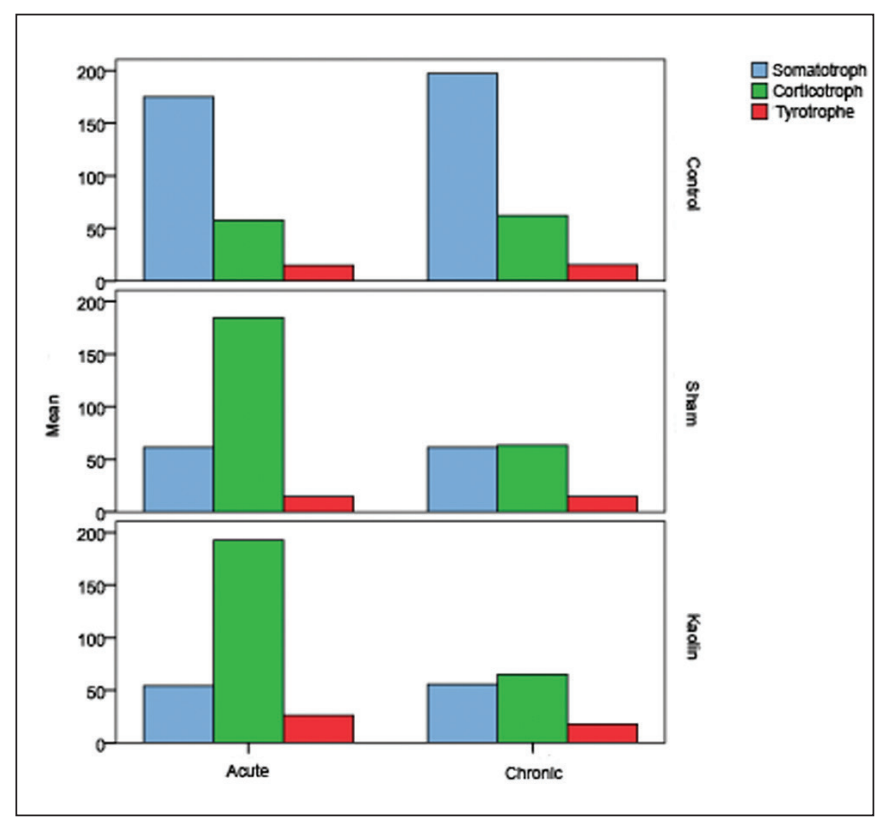

Figure 10: Distribution of cell groups according to the experimental groups. 
that high somatomedin-C levels associated with hydrocephalus in the patient reduced after a ventriculoperitoneal shunt was placed. They also suggested that this condition was due to a hypothalamic deformity (12).

Azzi stated that ICP changes can cause irregularities in the vasculature of the pituitary gland, and associated ventricular distortion could lead to endocrine disorders by creating pressure in many nourishing arteries, and that changes in ICP occur both in the median eminence and in the microvascular structure in the posterior portion of the pituitary gland (1).

From the above discussion, it is clear that while there are a few studies on hydrocephalus, hydrocephalus-induced brain parenchymal pathological changes, and the biochemical response of the pituitary gland, there are no studies on light microscopic evaluation of histopathological changes in the pituitary gland in a kaolin-induced hydrocephalus model. Thus, we demonstrated the progress of acute and chronic endocrinopathy in kaolin-induced hydrocephalus using a light microscope.

Herein, we evaluated the following cell groups: somatotropic, corticotropic, thyrotropic, mammotropic, and gonadototropic cells. Somatotropic cells release $\mathrm{GH}$. The observed reduction in these cells is thought to be due to hydrocephalus caused by disruption of CSF flow and kaolin-induced inflammation in the acute and chronic phases. There were no significant differences in terms of somatotropic cell concentrations between the acute and chronic kaolin groups, indicating that growth hormone secretion is equally sensitive to the acute and chronic phases of increased ICP. Significant reduction in somatotropic cell concentrations in the acute and chronic groups, when compared with the respective control groups, indicates that CSF flow changes can occur despite removal of an equivalent aliquot of CSF. Further, there was significant increase in somatotropic cell concentration in the chronic kaolin group compared with that in the chronic sham group, suggesting that the cause of the persistent elevation in ICP is due to hydrocephalus in the chronic group.

Corticotropic cells are the cells that release ACTH. When the acute kaolin and sham groups were compared with the acute control group, corticotropic cell concentrations were higher with the increase in the kaolin group being more marked than in the acute sham group. In the acute sham group, this was attributed to fluctuations in ICP, but in the acute kaolin group, the attributable reason was widespread inflammation due to kaolin and the stress response to hydrocephalus. Corticotropic cell concentrations in the chronic control, chronic sham, and chronic kaolin groups did not change possibly due to the fact that this timepoint represents the initiation of the integration process during hydrocephalus, especially in the chronic phase. This contrasts with the stress response in the acute phase, which probably disappears or reduces the stress response.

Thyrotropic cells release TSH. When the acute control group was compared with the acute sham and kaolin groups, a small increase in thyrotropic cell concentrations was observed, which was slightly more than the increase in the acute sham group; however, this result was statistically insignificant.
Mammotropic cells release PRL, and gonadotropic cells release $\mathrm{FSH}$, and $\mathrm{LH}$. In these groups, there was no difference between the control, sham, and kaolin groups, either during the acute or chronic phases. From the above result, it can be hypothesized that the most important effect of hydrocephalus that leads to pituitary dysfunction was on the somatotropic cell group and that this effect can be predominant during the acute and chronic phases. Further, we also believe that the corticotropic cell responses may be variable, as seen in literature. It has been determined that the increase in cortiotropic cell concentrations in the acute sham and chronic kaolin groups depended on intracranial pressure fluctuations, and increased ICP as a stress response, respectively. Thus, increase in corticotropic cell concentrations in the acute sham and chronic kaolin groups was associated with ICP fluctuations and an associated stress response that occurred due to elevated ICP.

\section{CONCLUSION}

We can conclude that it would be appropriate for pituitary hormone levels to be clinically evaluated before and after surgical correction in the presence of hydrocephalus. We think that this may help to prevent unnecessary hormone treatments in surgically corrected pituitary dysfunction. As noted in several publications, pituitary dysfunction is often associated with the deficiency of a few hormones rather than deficiency of all hormones. While our study concurs with those in the literature, further studies are indeed warranted.

\section{ACKNOWLEDGEMENTS}

Preparation for publication of this article is partly supported by Turkish Neurosurgical Society.

We would like to thank Dr. Aslıhan Alhan for statistical analysis of this study.

\section{REFERENCES}

1. Azzi GM: Hydrocephalus-induced changes in the endocrine hypothalamus of the hamster. J Bras Neurocirurg 5(2):4560,1994

2. Azzi GM, Canady Al, Ham S, Mitchell JA: Kaolin-induced hydrocephalus in the hamster: Temporal sequence of changes in intracranial pressure, ventriculomegaly and whole-brain specific gravity. Acta Neuropathol 98:245-250, 1999

3. Bilginer B, Çataltepe O: Hidrosefali: sınıflama, Patofizyoloji ve Tedavisi. Temel Nöroşirürji. Ankara: Türk Nöroşirürji Derneği 2010:1899-1910

4. Del Bigio MR: Cellular damage and prevention in childhood hydrocephalus. Brain Pathol 14:317-324, 2004

5. Del Bigio MR, C da Silva M, Drake JM, Tuor IU: Acute andechronic cerebral white matter damage in neonatal hydrocephalus. Can J Neurol Sci 21: 299-305,1994

6. Greenberg MS: Handbook of neurosurgery. New York: Thieme Medical Publishers, 5th ed. 2001:164-166 
7. Löppönen T, Paakkö E, Laitinen J, Saukkonen AL, Serlo W, Tapanainen P, Ruokonen A, Pirttiniemis P, Poikelas A, Knip M: Pituitary size and function in children and adolescents with shunted hydrocephalus. Clin Endocrinol 46:691-699, 1997

8. Löppönen $T$, Saukkonen AL, Serlo W, Tapanainen $P$, Ruokonen A, Knip M: Accelerated pubertal development in patients with shunted hydrocephalus. Arch Dis Child 74:490496, 1996

9. Löppönen $T$, Saukkonen AL, Serlo W, Tapanainen $P$, Ruokonen A, Knip M: Reduced levels of growth hormone, insulin-like growth factor-I and binding protein-3 in patients with shunted hydrocephalus. Arch Dis Child 77:32-37,1997
10. Moin T, Bergsnedider M, Vespa P, Heaney PA: Pituitary function in patients with normal pressure hydrocephalus before and after neurosurgical correction. J Clin Endocrinol Metab 97: 3345-3549, 2012

11. Mutluer S: Hidrosefali: klinik ve tedavi. Temel Nöroşirurji. Ankara: Türk Nöroşirurji Derneği, 2010:1911-1921

12. Okada $Y$, Kawamoto S, Yoshida S: High serum levels of somatomedin- $C$ and diabetes mellitus caused by obstructive hydrocephalus: Case report. Neurosurgery 42:1172-1175, 1998

13. Taner D: Ventriküler Sistem ve Liquor Cerebro Spinalis. Fonksiyonel Nöroanatomi 5. Baskı, Ankara: 2004:29. 